\title{
Resistance, Unrest, Protest and Demonstration Provoked by COVID-19: A Case Study of Bangladesh
}

\section{A H M Nahid*}

Department of Development Studies, Faculty of Social Sciences, Islamic University, Kushtia-7003, Bangladesh.

*Correspondence: nhasnatnahid@gmail.com (A H M Nahid, Lecturer, Department of Development Studies, Faculty of Social Sciences, Islamic University, Kushtia-7003, Bangladesh).

\begin{abstract}
Covid-19, the pandemic, has been wreaking havoc all around the globe including Bangladesh since its inception in China. Not only has the virus been a great threat to human life, but it has also affected the economic, political, and social aspects of life-generating resistance issues, a number of unrests, protests, and demonstrations. This study, following a mixed methodology, tries to identify the incidence and nature of these social issues brought about by Covid-19. The study finds that both the expatriates and the residents of the country continuously defied the lockdown and social distancing rules as the government had tried to contain the covid19 through those measures. While the motive for the expatriates was to get away from the authorities and get back home, apathy to follow the new rules, food and work opportunities, job security, and even marriage was the stimulus for the general people to bypass the laws. Unrests like the spreading of rumors, price hikes, a rise of crime, etc. shook all 64 districts of the country. Covid-19, directly or indirectly, provoked more than 250 protests and demonstrations. While the existence of demand for relief or complaints regarding relief distribution was the main incentive for the people of all ages and occupations, reasons such as demand for remuneration and incentives, safety equipment and facilities, closure of educational institutions as well as hospitals, halting specialized hospitals were evident.
\end{abstract}

Keywords: Resistance, Unrest, Protest, Social response, Demonstration, COVID-19, and Bangladesh.

\section{INTRODUCTION:}

Novel Corona Virus first emerged in Wuhan, China as the earliest case was detected on November 17, 2019 (Davidson, 2020). International Committee on Taxonomy of Viruses (ICTV) named the virus as 'severe acute respiratory syndrome coronavirus 2' (SARSCoV-2) (ICTV, 2020). The novel corona virus was named COVID-19 by WHO on February 11, 2020 (BBC News, 2020). The virus began to spread and reached Europe, France to be exact, in December, 2019(BBC News, 2020). Later, the outbreak was declared a global pandemic by WHO (Gumbrecht \& UniversePG I www.universepg.com
Howard, 2020). The first cases of Covid-19 were detected in Bangladesh on March 8, 2020 (Jugantor, 2020). It is thought that the virus entered Bangladesh through expatriates as the first three cases were all expats from Italy (Business Standard, 2020). Since then, the pandemic has been affecting Bangladesh. People are mostly concerned by the health issues caused by covid-19, but the impact of the virus on economic, political, and social life is also very significant. The pandemic has greatly impacted the lives of the people spawning resistance issues, different types of unrests and many protests and demonstrations. 
Resistance, in a general sense, refers to denial to accept someone or something. Resistance, in the paper, refers to the refusal of the people of Bangladesh to abide by the new rules and restrictions such as lockdown measures, social distancing rules, provision to make the masks mandatory etc. imposed by the Government to contain the covid-19. The term also encompasses the actions and/or innovations of the law-abiding citizens while combating others' improper behavior, social problems, etc. Unrest indicates the social problems such as spreading of rumors, price hike, increase of crime and violence against women, and challenges against freedom of expression that the covid-19 has given rise to. Protest and demonstration consist of issues like demand for relief/support, improper distribution and/or corruption, asking for rights and remuneration, and safeguarding own rights.

The objective of the study has been to explore the incidence and nature of the Covid-19 caused issues, resistance, unrest, protest and demonstration, in Bangladesh. The study demanded mixed methodology and data collection as well as analysis to be applied and so a blend of qualitative and quantitative data is used. The data are collected from eleven leading dailies of Bangladesh: Prothom Alo, Jugantor, Daily Observer, Daily Star, New age, Financial Express, Naya Diganta, Kaler Kantho, Business Standard, Dhaka Tribune and also news from a few online web portals those are related to the subject matter of the study. All the data come from news of the sources from March 10, 2020 to May 6, 2020. However, the study has several limitations. The study has used the data from news sources to explore the incidence of the issues. It is acknowledged that data from newspapers can be biased, unreliable, politically influenced, and entertain-centered, not fact-centered. But major research traditions in social movements have used the newspapers as data sources. Newspaper event data was used as the basis in the development of political process model (Jenkins \& Perrow, 1977). Studies on political opportunities (Tarrow, 1989), protest cycles (Koopmans, 1993), ethnic violence (Olzak, 1992), rioting (Danzger, 1975), global collective action (Taylor \& Jodice, 1983), and repression and protest control (Earl, et al., 2003) have relied on this kind of data. In additions, the study didn't explore the theo- retical domain as it had been accepted that the incidences were happening and the idea was to investigate their intensity and nature. As a result, more focus was laid upon the collection and analysis of primary data. Despite having several limitations, the study chronologically discloses the incidence and nature of Covid19 precipitated resistance, unrest, protest and demonstration happening in Bangladesh.

\section{COVID-Generated Resistance Issues}

Since the inception of Covid-19 cases in Bangladesh, the government has been trying hard to maintain social distancing and lockdown procedures. But the citizens have shown significant resistance to those decisions and often violated the restrictions imposed on them. Before the cases emerged in March, the government had been trying hard to quarantine the in-coming expatriates. But the returnees had shown significant resistance to that decision. Some tried to flee the quarantine (New Age, 2020), some protested (Daily Observer, 2020), and some just made farce of quarantine (Daily Star, 2020). They just roamed around in quarantine (Daily Star, 2020). In response, they were often fined by the local authorities and law enforcing administration (Prothom Alo, 2020).

Table 1: Lockdown Situation in Bangladesh

\begin{tabular}{|l|c|c|c|}
\hline $\begin{array}{c}\text { Units/Lock } \\
\text { down } \\
\text { Scenario }\end{array}$ & $\begin{array}{c}\text { Not Locked } \\
\text { Down }\end{array}$ & $\begin{array}{c}\text { Partially } \\
\text { Locked } \\
\text { Down }\end{array}$ & $\begin{array}{c}\text { Fully } \\
\text { Locked } \\
\text { Down }\end{array}$ \\
\hline Division & 0 & 5 & 3 \\
\hline District & 3 & 12 & 49 \\
\hline Upazila & 82 & 17 & 395 \\
\hline
\end{tabular}

Source: https://corona.gov.bd/lockdown-status

Like the expatriates coming to the country, the foreigners also defied the mandatory quarantine rules (New Age, 2020). The case was the same for citizens of the country. The government declared lockdown procedures for every region when at risk. The Table 1 illustrates the situation of lockdown in Bangladesh on May 6, 2020. The only three districts free from lockdown were Jhenaidah, Magura, and Meherpur from Khulna Division. The government declared public holiday for all on March 24 (Daily Observer, 2020). The government also deployed the army to control public movements. But all went in vain as the govern- 
ment declared entire Bangladesh at risk of covid-19 infection on April 16, 2020 (Daily Star, 2020). This happened because the Bangladeshi citizens visited markets, malls violating restrictions (Daily Observer, 2020). Interestingly, nearly 25,000 people attended a special prayer in Laxmipur to pre-vent the spread of covid-19 (New Age, 2020). People continuously defied and showed extreme resistance against the governmental restrictions. The central and local administration also imposed extreme measures like fines, jailing etc. But all those efforts failed to confine people to their homes. The highest number of people fined in a single day was 235 (Daily Observer, 2020). The greatest blow, maybe, was dealt by the public movement on March 25 after the government had declared general holiday while notifying it was only to stay indoors (case study 1). The people didn't comply. Despite ban on public transports, people rushed to bus terminals, train stations, waterway terminals etc. and caused huge gathering. The people either didn't get what the government asked for or they didn't want to. The movements didn't stop on March 25. The movements continued till the end of March. People continued to move around the country through good-carrying vehicles (New Age, 2020).

\section{Case Study 1: Bangladesh sees mad rush for home despite ban on public transports}

The authorities close all public transport services on railways, waterways, and domestic airways in the country while thousands of people overcrowd the terminals in the capital as the government announced a 10-day public holiday yesterday. Movement of passénger trains, launches, and domestic flights would remain suspended until further notice to check the spread of covid-19. Road transport and bridges ministry also imposes a 10-day ban on movement of all public transports on roads from tomorrow. All goods carrying vehicles on roads, railways and water-ways remain outside the purview of the bans. Soon after the government declared holiday for government and nongovernment organizations, thousands of people started to leave Dhaka which has turned into a mad rush on the following day. Different trains and launches cram with passengers while no special measures are taken to tackle such rush at these terminals and for following health directives to avoid coronavirus infection. Bus UniversePG I www.universepg.com passengers suffer more due to extra fares charged by bus owners plying different routes and many of them are forced to get on goods carrying vehicles risking their lives. The government on Monday declared the public holidays for between March 26 and April 4 for maintaining social isolation which the experts suggested to prevent the coronavirus spread. On the previous day, Principal Secretary to the Prime Minister's Office, at a press briefing, requested the employees to stay at home to prevent coronavirus stating that the public holiday was not declared for celebration but to stay at home. The mad rush to leave the city began after that and thousands of people were seen at all railway, waterways, and bus terminals in the capital. Several homebound people said that they were going to their ancestral homes as they felt Dhaka was more vulnerable to the spread of the virus compared with their village homes while others said that since they were given a long vacation, they would like to spend it with their families.

Fines against drivers (Daily Observer, 2020) and cases couldn't stop the people. The covid-19 continued to spread as carriers and affected people relentlessly roamed around the country. The social distancing procedures had dealt another great blow on April 17, 2020 (Dhaka Tribune, 2020) as nearly one hundred thousand people from different districts attended the Namaj-e-Janaza prayer (Islamic funeral prayer) of an Islamic leader in Brahmanbaria district. Thousands came from different districts and the home minister later responded notifying that they didn't know anything about the incident beforehand (Prothom Alo, 2020).

This event marked another big failure in controlling public movement. While trying to identify the reasons behind public movement, it has been identified that food and work was the main factors causing public movement. A report entitled 'People defy national shutdown in search of food and work' on New age (March 31, 2020) shows us public desperation in search for food and work as the poor roamed around the capital (Dhaka) despite high infection risk as well as high restrictions by the authority. The poor were also seen on street corners on April 25 as the shutdown continued (New Age, 2020). A female food seeker quoted: 
"I came here to collect food as I need to feed my children... where do I get food? I waited a few days but came out on the street today." (New Age, 2020)

Another job-seeking day laborer lamented for lack of job opportunities saying:

"I am an able-bodied man. How can I take to begging?"(New Age, 2020).

Though the food and work were the main factors pulling people out of their residuals, they weren't the only ones. Private tuition was another factor causing public movement. The local authorities fined and jailed private tutors on several occasions (New Age, 2020; Daily Star, 2020; Jugantor, 2020; Daily Observer, 2020). Job security was another high impact pull factor. Thousands of RMG workers rushed back to their working areas in fear of losing their jobs on April 4, 2020 (Daily Star, 2020). Another engrossing factor pulling people out of government restrictions was marriage. Many people chose the public holiday due to covid-19 as a suitable occasion for getting married. This was a so compelling idea that even some government officials fell into its prey! A civil surgeon in Brahmanbaria was the first of a few government officials (among reported ones) to cause a gathering by getting married and thus defied governmental rules and regulations (New Age, 2020). In this occasion, several doctors attended accompanied by nearly three hundred attendees. Another government official, an Upazila family planning officer in Sonargaon, Narayanganj was fined Tk 10,000 by mobile court for arranging marriage ceremony (Jugantor, 2020). In both cases, the offenders claimed that the dates of occasions were pre-determined. But these acts show us that even the government officials were not aware of or not ready to abide by the restrictions introduced by the Government.

\section{Case Study 2: Youth from capital shows innovation by demonstrating relief distribution while maintaining social distance}

The government had asked all the citizens to stay at home and maintain social distance to prevent the spread of covid-19. Responding to that, citizens were staying at their own residence. But day-laborers and people with low income had fallen into trouble. In UniversePG I www.universepg.com response, the wealthy were extending their helping hands to the distressed. Distributing relief had become challenging as it was creating gatherings that hampered social distancing. This was creating risks of exposure towards covid-19. In these circumstances, three youth from Dhaka has demonstrated an innovative way of relief distribution. Before relief distribution, they drew circles, maintaining a distance of three feet, and placed one receiver in each of the circles. After the first person receives the relief and leaves, the next person enters the circle. In such a way all the distressed collected relief on by one. The threeyouth distributed 450 kilograms of rice, lentil, and potato on the day. The police also helped the cause.

Stories of actual resistance, following governmental restrictions, trying to refrain people from breaking rules or innovating ways for maintaining social distancing were few but present. Obstruction of home quarantine caused a clash in Kaliganj, Jhenaidah (Kaler Kantho, 2020) while an attempt by the neighbors to abstain a Dhaka-returned person from going out failed in vain. The neighbors tried their hard to refrain the family while strong intolerance gave rise to a clash which left four people injured. Another noticeable incident was the mob torching a boat for carrying covid-19 suspects in Sirajganj (New Age, 2020). Although the covid-19 was able to bereave the Bangladesh is off the festival of Pahela Baisakh (BenarNews, 2020), it couldn't stop the farmers of Netrokona from harvesting Paddy (Daily Observer, 2020). Another inspiring story of resistance was the innovation of three youth from Dhaka (case Study 2). The relief distribution was presenting a challenge because huge gatherings were increasing covid-19 risks (Financial Express, 2020). The three youth from Dhaka demonstrated an innovative way of relief distribution while maintain social distancing and keeping the corona infection risks low. While most of the efforts of the government to control public movement or enforce laws to keep covid-19 infection low either went in vain or back-lashed, some of them met sad outcomes. One of the most discussed incidents of the country happened when an Assistant Commissioner (land) took the photo of the punished people and posted it on social media. The action was met with immense criticism around the country and 
the assistant commissioner (land) was eventually withdrawn (Daily Observer, 2020). Another sad event happened in Natore when the efforts of a village police officer were met with boiled water thrown at him by a tea dealer (Prothom Alo, 2020).

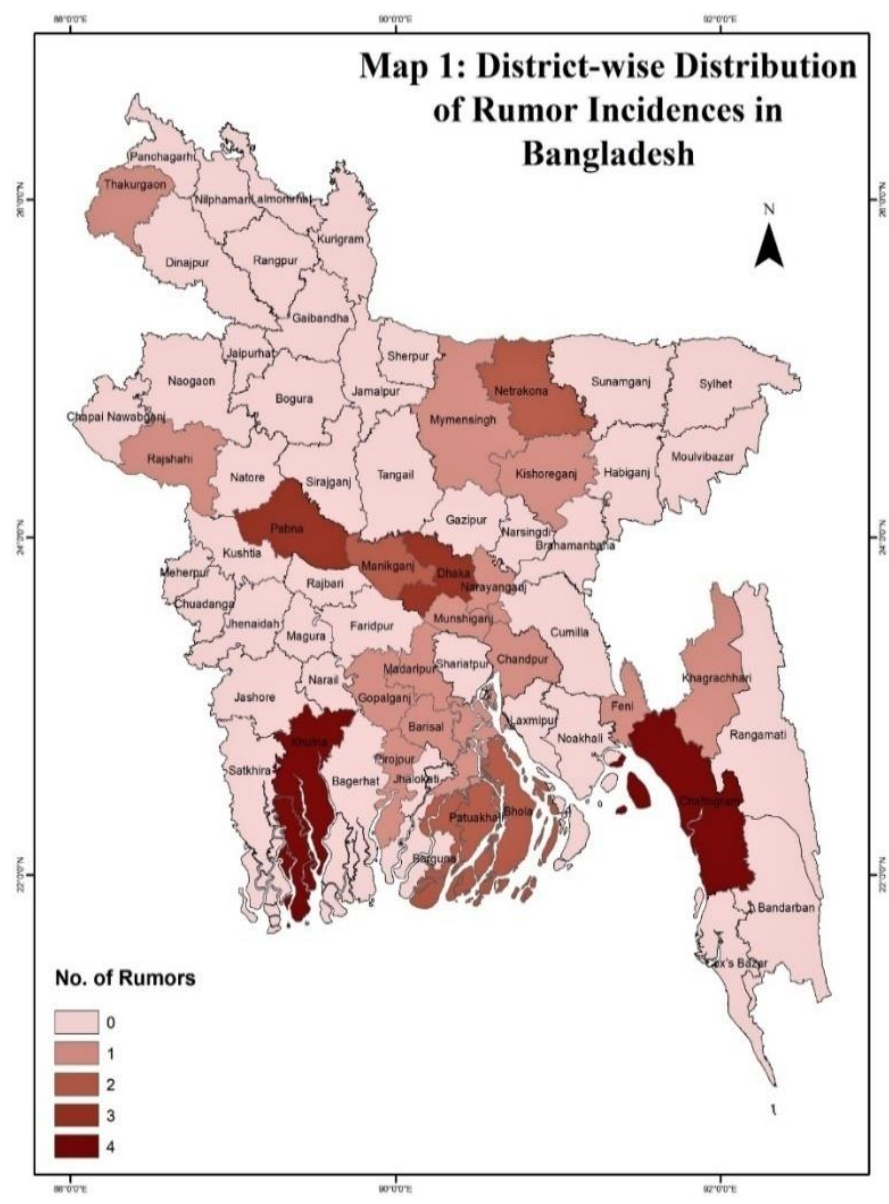

\section{COVID-Induced Unrest}

Different types of unrest had spawned due to covid-19 and the situation it created. One of the most significant types of unrest was the spread of rumor. While trying to prevent the spread of covid-19, the government of Bangladesh had to combat different rumors about the disease. 21 districts, out of 64, were directly affected by different types of rumors. Map 1 illustrates the affected districts and the frequency of rumor in those districts of Bangladesh. Chattogram and Khulna are the two districts where the rumors had raised the most (4 times). Pabna sides with Dhaka as 3 incidents of rumors occurred in each. Four Districts, Netrokona, Patuakhali, Manikganj and Bhola, each experienced different types of rumors twice about corona virus. Each of the other 13 districts experienced the covid-19 rumors at least once.
Case Study 3: Thankuni Leaf can prevent Corona!

A new rumor that Thankuni leaf cures coronavirus disease had spread in different districts of Bangladesh. A section of people were spreading the rumor. It had been told that eating three Thankuni leaves was enough to fight coronavirus. Many had given posts in social media justifying its fruitful side. Miking had been done in the mosques supporting the rumor. Many people ate Thankuni leaves in the faith that they would not get infected by covid-19. In his Facebook post, a villager from Goplaganj had urged all to eat Thankuni leaves. Another from the same division said that an announcement from a local mosque had suggested taking three Thankuni leaves and he had eaten three leaves after hearing it. The center of the rumor was a Pir who had quoted to get the message (that by eating three leaves with salt could check coronavirus attack) in a dream. Hearing this, men and women from different regions of the country had started searching out Thankuni leaves with lights at midnight. After collecting leaves at night, many had taken those leaves. Another Islamic Scholar said that it was totally a falsehood and rumor. Thankuni leaves are useful for dyspepsia. Experts said that there was no basis in health science that viral diseases like covid-19 could be cured by taking Thankuni leaves.

The type of rumors was different. Some rumors were about vaccine for covid-19 (Jugantor, 2020), some were about corona infection (Jugantor, 2020), and some were about spreading Covid-19 preventive medicines (Bangla News 24.com, 2020). Case study 3 shows how a Pir's (a religious leader) dream inspired many people to go out for collecting Thankuni leaf as it could be used to prevent covid-19. This rumor touched at least five districts of the country. The problems regarding rumors became so bad that the cyber police had to play a vigilant role. The highest numbers of arrests by the cyber cops were 28 in a day (Daily Observer, 2020). About this, Inspector General of Police said:

"Harsher action will be taken if anyone spreads misleading information and rumors about coronavirus through social media." (Daily Observer, 2020) 
People from different professions like doctor (New Age, 2020), engineer (Daily Observer, 2020), police (Jugantor, 2020), general people etc. were acting as rumormongers. There was also a political dimension to this. While people from opposition parties like Jubo Dal (student wing of an opposition political party) tried to gain by spreading rumor (New Age, 2020), the followers and leaders of the party in-power didn't lay behind (Jugantor, 2020). The responses to these rumors were also different. Some rumors were successful by making people fall for them (as the case study 3 shows), some were met with harsh outcomes as the rumormongers met public rage (Jugantor, 2020). Some of these rumors even obstructed health service delivery in hospitals (Jugantor, 2020).

The fear about covid-19 was also used by different groups to gain their selfish goals. While the panic-buy by people pushed the prices up (Daily Observer, 2020), the dishonest businessmen used the panic to hike prices of different commodities. The government imposed strict measures on them as many were fined for this (Daily Star, 2020). Miscreants used this opportunity for gaining their goals of theft, rape (Daily Observer, 2020), murder etc. The covid-19 lockdown situation turned out to be a strong factor influencing a sudden rise in violence against women. The violence against women rose significantly (Daily Star, 2020). While a man was arrested with 'virus shut out' products (Daily Observer, 2020), storing and selling corona test kits illegally also happened (Prothom Alo, 2020). While trying to control rumors regarding covid19, serious attacks on freedom of expression happened. While teachers on two occasions were suspended for their comments (Dhaka Tribune, 2020), journalists were also sued for specific news (New Age, 2020). These actions met criticisms and resulted into a lot of protests and demonstrations.

\section{COVID-Triggered Protest and Demonstration}

There were serious irregularities in relief distribution in Bangladesh (Financial Express, 2020). One of the main reasons for either protest of demonstration by people was either demand for relief or irregularities in relief distribution. From March 10, 2020 to May 6, 2020, total 149 incidents took place in 43 districts where people protested for relief. Besides, people from 41 districts either protested or demonstrated against relief distribution procedures or, requested for relief 57 times. In all the 64 districts of Bangladesh, incidents like protest for relief, protest against improper relief distribution, news about relief-related misconduct, request for relief distribution occurred at least once. Map 2 illustrates the districts with highest frequency of protests held by relief-wanting people in Bangladesh. Surprisingly, Jashore (12) tops the lists followed by the capital, Dhaka (11) and Chattogram (9). Another divisional center, Rangpur (8) stands next in the line.

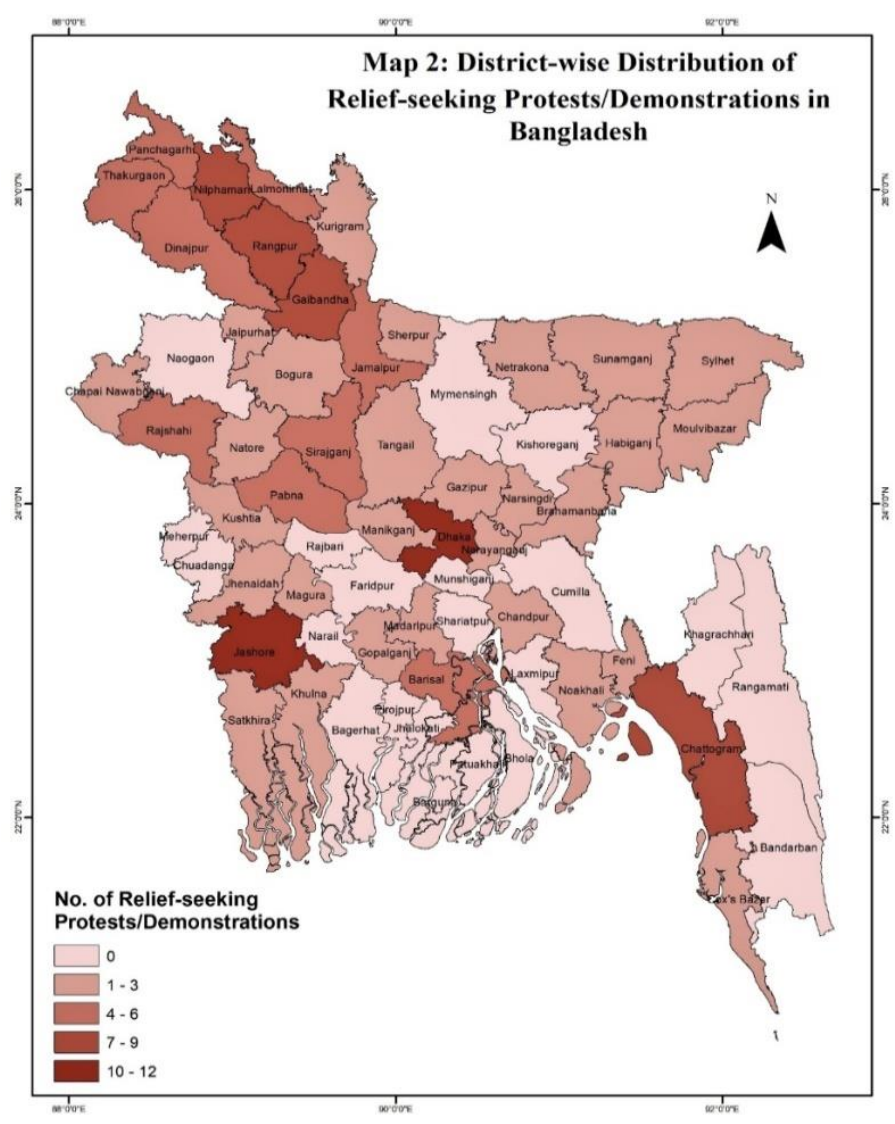

Both Nilphamari and Gaibandha faced 7 protests each by the poor. Pabna, Rajshahi encountered six protests each for relief while Lalmonirhat and Sirajganj recorded five movements by relief-seekers. The needy also staged four protests in each of Jamalpur, Panchagarh, Dinajpur, Thakurgaon and Barisal. Madaripur, Tangail, Narayanganj, Chandpur, Kurigram, Bogura, Satkhira and Kushtia are the districts where protests for relief had taken place thrice. People from Narshingdi, Gopalganj, Sylhet, Sunamganj, Feni, Brahmanbaria, Chapai Nawabganj, Khulna and Gazipur protested twice wanting relief distribution. Demonstration for 
relief happened once at Manikganj, Sherpur, Netrokona, Moulvibazar, Habiganj, Noakhali, Cox'sBazar, Natore, Jaipurhat, Magura and Jheinaidah.

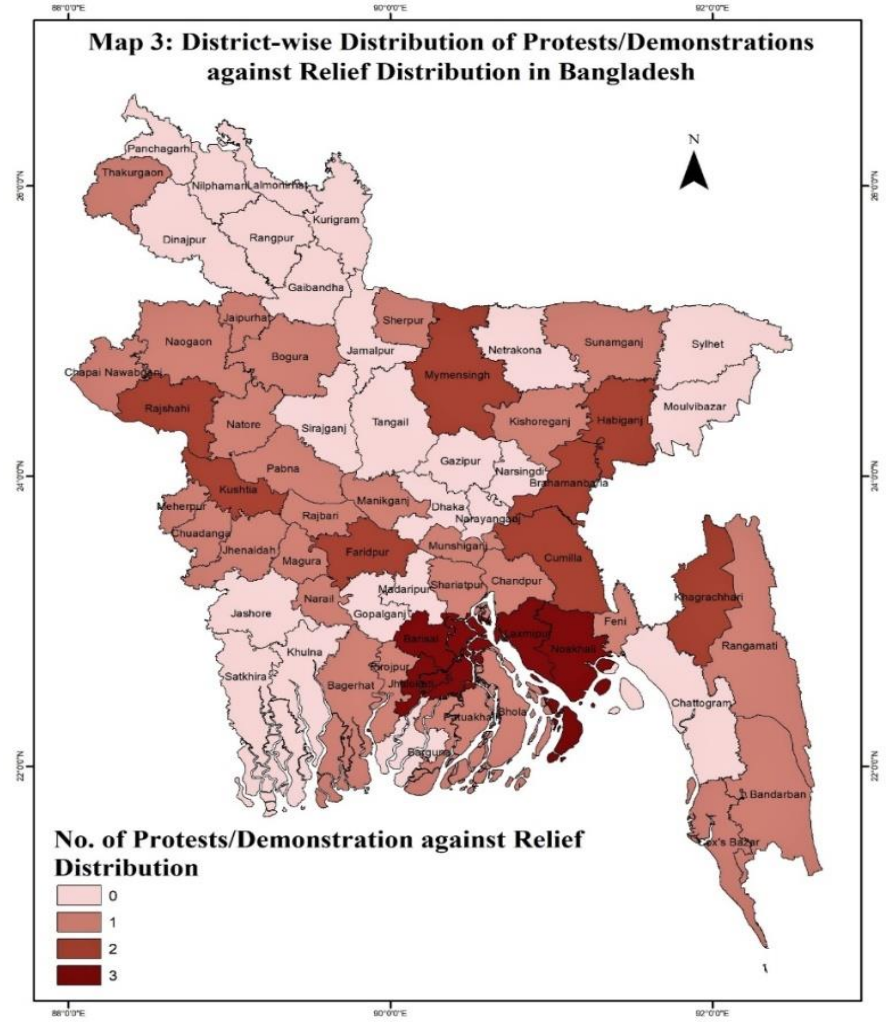

Protests or demonstrations also happened against irregularities regarding relief distribution. People expostulated against relief distribution in 41 districts (illustrated in Map 3). Of those districts, Noakhali, Laxmipur, Barisal and Jhalakathi are the districts where people dissented thrice. In Faridpur, Mymensingh, Habiganj, Cumilla, Brahmanbaria, Khagrachari, Rajshahi and Kushtia, people complained twice about obliquity in relief distribution. People also raised complaints about relief distribution at least once in Shariatpur, Kishoreganj, Manikganj, Munshiganj, Rajbari, Sherpur, Sunamganj, Feni, Chandpur, Cox'sBazar, Bandarban, Rangamati, Thakurgaon, Pabna, Bogura, Natore, Jaipurhat, Chapai Nawabganj, Naogaon, Meherpur, Narail, Magura, Jhenaidah, Chuadanga, Bagerhat, Patuakhali, Bhola, and Pirojpur districts. In one of these protests, even the UP members protested against the UP chairman (Jugantor, 2020). About irregularities in relief distribution, a protestor quoted:

"The relief has been distributed thrice in our area.

But it was not us, the poor and needy, who got the relief." (Jugantor, 2020)

\section{Case Study 4: Fake demonstration arranged to cover relief theft!}

The Anti-Corruption Commission filed a case of relief theft against a UP Chairman in Narail. To tackle this, the UP Chairman arranged a demonstration in his area using his own resources and power. People were made to attend the demonstration while not maintaining the regulations regarding social distancing. The Chairman was found guilty of seizure of relief materials, VGD (Vulnerable Group Development) goods to be exact. He seized 40,800 kilograms of relief materials for 16 consecutive months. Many people criticized the demonstration as it had broken social distancing rules. Locals said that the chairman was highly corrupted and so desperate that he could attend the demonstration. Some expressed that they were forced to join as they feared the chairman. The people of the Union were happy that the chairman was found guilty by the Anti-Corruption Commission; but none dared to say anything. Locals claimed that the chairman who was involved in drug trade as well as the killing of a number of people had a group of followers. Some also accused the chairman of being a gambler and drug addict. The administration was said to be inquiring the situation.

In some cases, the accused also went for demonstrations to back his activities (see case study 4). A UP Chairman in Narail, using his influence, staged a demonstration that shows the public support in his favor when he had been apprehended by the AntiCorruption Commission - Bangladesh (an independent corruption detective as well as preventive institution of the state). It was not only the poor who protested or demonstrated for relief; rather people from different professions arranged movement's demanding relief. Hotel workers staged protest for relief (Jugantor, 2020). CNG Taxi drivers protested for relief in Dhaka (Jugantor, 2020). Sramik Karmachari Oikkya Parishad (SKOP), an organization of jobless workers demanded relief for them (New Age, 2020). Fishermen in Patuakhali protested demanding relief as they weren't getting VGF (vulnerable group feeding, VGF, is a social safety net program in Bangladesh) facilities (Naya Diganta, 2020). The city cleaner demonstrated demanding covid-19 compensation (New Age, 2020). 
Transport workers staged demonstrations all over the country for relief (New Age, 2020).

Minority groups like the Biharis (Jugantor, 2020)and different ethnic groups protested for relief. Although the struggles for rights and/or facilities were new for them, it wasn't new for readymade garment (RMG) workers in Bangladesh. They not only had to rush back to workplaces in fear of job security (Daily Star, 2020) but also had to protest and demonstrate for getting their payments and rights-related to workplace safety. More than 30 protests by the RMG workers took place in Bangladesh (Daily Star, 2020) and some of those ended in clashes (Daily Star, 2020). The same can be said for Jute Mill workers (Jugantor, 2020), Sugar Mill workers (Jugantor, 2020) etc. Even the people working on the frontline of fight against covid19, the doctors (Daily Star, 2020) and the nurses (Business Standard, 2020) had opt for protests and demonstrations demanding safety equipment and facilities like PPE, quality masks, etc. Apart from the working class, people from other spheres also staged protests for safety rights. Students, particularly from the universities, had to protest trough demonstrations, boycotts, etc. for the closure of the institutions (New Age, 2020). Not all of the protests happened based on rights issues; some were also driven by fear. Due to the protests by the people consumed by the fear of Covid-19, the government had a lot of trouble setting treatment facilities. While setting up quarantine centers, locals protested (Dhaka Tribune, 2020). Protests happened in Kishoreganj against the selection of Syed Nazrul Medical College Hospital for Corona treatment (Prothom Alo, 2020). Fear-driven people went to such an extent that they even halted the construction of a hospital that was meant to treat Covid-19 patients (New Age, 2020).

\section{CONCLUSION:}

The aim of the study has been to unpack the incidence and nature of the resistance issues, unrests, protests and demonstrations, in Bangladesh sparked off by covid-19. People showed significant resistance to the new rules like lockdown measures and social distancing rules. In some cases, the motives (want of food and work, job safety etc.) behind resistance was reasonable whereas grounds like apathy to follow safety measures, getting away when sick, marriage etc. deserved strict measures to be applied. The government tried to deal with the resistance issues, but most of the attempts was untimely, unsuccessful, and often, backfired. Individual and collective measures to make people follow those rules were present; but they also turned violent. Rumors appeared to be the best way to gain selfish goals and they were used abundantly by the people, regardless of their occupation, age and/or political identity. Unrests like violence against women, theft, fraudulence, etc. also rose not-ably. People often came out to join protests and demonstrations wanting relief, proper relief distribution, action against corruption, payment, remuneration, safety facilities, etc. The fear of covid-19 intensified in Bangladesh because the government as well as the citizens had to combat issues not only health-related risks but also problems provoked by the pandemic that had economic, social, and political dimensions. The incidence of the problems was bountiful while the nature appeared to be diverse. The response, to fight the plentiful and diverse issues, appeared to be unsuccessful; but proper policymaking and implementation can help the nation combat the problems and cope with the 'new normal' in the postCovid era.

\section{ACKNOWLEDGEMENT:}

I highly acknowledge and thank Md. Inzamul Haque (Lecturer, Department of Environmental Science and Geography, Islamic University, Kushtia-7003, Bangladesh) for his assistance in preparing the maps used in the paper. I would like to thank the undergraduate students of $1^{\text {st }}$ Batch of Department of Development Studies, Islamic University, Kushtia-7003, Bangladesh for their kind support in content searching that assisted in data collection for this research.

\section{CONFLICTS OF INTEREST:}

The author whose name is listed immediately below certify that he has no affiliations with or involvement in any organization or entity with any financial interest (such as honoraria; educational grants; participation in speakers' bureaus; membership, employment, consultancies, stock ownership, or other equity interest; and expert testimony or patent-licensing arrangements), or non-financial interest (such as personal or professional 
relationships, affiliations, knowledge or beliefs) in the subject matter or materials discussed in this manuscript.

\section{REFERENCES:}

1) Bangla News 24.com, (2020). হেলিকপ্টার থেকে করোনা প্রতিরোধী ওষুধ ছিটানোর গুজব. Available at:

https://www.banglanews24.com/national/news/b $\mathrm{d} / 779401$. details

2) BBC News, (2020). Coronavirus disease named Covid-19. Available at:

https://www.bbc.com/news/world-asia-china$\underline{51466362}$

3) BBC News, (2020). Coronavirus: France's first known case 'was in December'.Available at:

https://www.bbc.com/news/world-europe-52526554

4) BenarNews, (2020). Pandemic Muffles New Year Festivities in Bangladesh, Other Countries. Available at:

https://www.benarnews.org/english/news/bengal i/bangladesh-coronavirus-04142020181704.html

5) Business Standard, (2020). Nurses plead not to be sent into 'corona battle unarmed'. Available at:

https://tbsnews.net/coronavirus-chronicle/covid19-bangladesh/nurses-plead-not-be-sent-coronabattle-unarmed-67996

6) Business Standard, (2020). দেশে প্রথম তিন করোনা রোগী শন্তাক্ত. [Accessed 6 May 2020].

7) Daily Observer, (2020). 11 drivers fined for carrying people in trucks. Available at: https://www.observerbd.com/details.php?id=2514

8) Daily Observer, (2020). 142 Italy returnees quarantined at Ashkona, some protest.

Available at: https://epaper.observerb d.com/2020/03/15

9) Daily Observer, (2020). 235 fined for different reasons in seven dists. Available at:

https://www.observerbd.com/details.php?id=252 $\underline{519}$

10) Daily Observer, (2020). Coronavirus: people thong shopping malls, markets ignoring warnings. Available at:

https://epaper.observerb d.com/2020/03/20

UniversePG I www.universepg.com
11) Daily Observer, (2020). Cyber cops step up vigil, arrest 28 rumor-monger. Available at: https://www.observerbd.com/details.php?id=252 021

12) Daily Observer, (2020). Engineer held for spreading rumors about corona virus. https://epaper.observerbd.com/2020/03/14/

13) Daily Observer, (2020). Farmers harvesting paddy at Khaliajuri amid corona fear. https://www.observerbd.com/details.php?id=253 $\underline{354}$

14) Daily Observer, (2020). Govt shuts offices from Mar 26 to Apr 4, Army called in.

Available at:

https://www.observerbd.com/details.php?id=250 $\underline{890}$

15) Daily Observer, (2020). Man held with "Virus Shut Out" product in city. Available at: https://www.observerbd.com/details.php?id=254 239

16) Daily Observer, (2020). Miscreants gang rape girl after entering home in guise of police. https://www.observerbd.com/details.php?id=251 $\underline{768}$

17) Daily Observer, (2020). Mobile court's punishment: Jashore AC (Land) withdrawn. https://www.observerbd.com/details.php?id=251 435

18) Daily Observer, (2020). One jailed for keeping coaching centre open. Available at:

https://www.observerbd.com/details.php?id=250 $\underline{366}$

19) Daily Observer, (2020). Panic buying pushes essential commodity prices up. Available at: https://epaper.observerbd.com/2020/03/21/

20) Daily Star, (2020). 90 businesses fined Tk 9 lakh for hiking price. Available at: https://www.thedailystar.net/city/news/90-busi nesses-fined-tk-9-lakh-hiking-price-1884145

21) Daily Star, (2020). Addressing the rise in domestic violence during lockdown. Available at: https://www.thedailystar.net/opinion/news/addre ssing-the-rise-domestic-violence-during-lockdo wn-1894618

22) Daily Star, (2020). Coaching centres open, defying govt directive. Available at: https://www.thedailystar.net/city/news/coaching -centres-open-defying-govt-directive-1882801\# 
23) Daily Star, (2020). Coronavirus: Govt declares entire Bangladesh at risk. Available at: https://www.thedailystar.net/government-declar es-entire-bangladesh-risk-coronavirus-covid-19pandemic-1893514

24) Daily Star, (2020). Demo for Pay: 25 hurt as $R M G$ workers, police clash in M'singh. Available at:

https://www.thedailystar.net/frontpage/news/de mo-pay-25-hurt-rmg-workers-police-clashmsingh-1890403

25) Daily Star, (2020). Farce of Quarantine. Available at:

https://www.thedailystar.net/frontpage/news/co mmentary-farce-quarantine-1881319

26) Daily Star, (2020). RMCH interns suspend work for four hours. Available at:

https://www.thedailystar.net/city/news/rmch-int erns-suspend-work-four-hours-1883158

27) Daily Star, (2020). RMG Workers: Thousands rush in, raise fear of spread. Available at: https://www.thedailystar.net/frontpage/news/rm g-workers-thousands-rush-raise-fear-spread1898155

28) Daily Star, 2020. RMG Workers: Thousands rush in, raise fear of spread. Available at: https://www.thedailystar.net/frontpage/news/rm g-workers-thousands-rush-raise-fear-spread-18 $\underline{98155}$

29) Daily Star, (2020). They roam around in quarantine!. Available at:

https://www.thedailystar.net/frontpage/news/the y-rove-about-self-quarantine-1880860

30) Danzger, M., (1975). Validating conflict data. American Sociological Review, 40(5), pp. 570-584. https://doi.org/10.2307/2094196

31) Davidson, H., (2020). First Covid-19 case happened in November, China government records show - report. Available at: https://www.theguardian.com/world/2020/mar/1 3/first-covid-19-case-happened-in-novemberchina-government-records-show-report

32) Dhaka Tribune, (2020). Coronavirus: Residents protest against quarantine centre in Uttara. Available at:

https://www.dhakatribune.com/bangladesh/natio n/2020/03/20/coronavirus-residents-protest-agai nst-quarantine-centre-in-uttara

UniversePG I www.universepg.com
33) Dhaka Tribune, (2020). 2 govt teachers suspended over 'critical' coronavirus-related FB posts. [Accessed 6 May 2020].

34) Dhaka Tribune, (2020). Social distance rule turned on its head by funeral crowd. Available at:

https://www.dhakatribune.com/bangladesh/natio n/2020/04/18/thousands-join-janaza-in-brahma nbaria-flouting-social-distancing-rule

35) Earl, J., Soule, S. A. \& McCarthy, J. D. (2003). Protests under fire? Explaining protest policing. Amer. Sociological Review, 68(4), 581-606. https://doi.org/10.2307/1519740

36) Financial Express, (2020). Coordinated food distribution maintaining social distance. Available at:

https://thefinancialexpress.com.bd/views/column s/coordinated-food-distribution-maintaining-soc ial-distance-1585845506

37) Financial Express, (2020). Unacceptable irregularities in relief operation. Available at: https://thefinancialexpress.com.bd/views/opinio ns/unacceptable-irregularities-in-relief-operati on-1587140905

38) Gumbrecht, J. \& Howard, J., (2020). WHO declares novel coronavirus outbreak a pandemic. Available at:

https://edition.cnn.com/2020/03/11/health/coron avirus-pandemic-world-health-organization/ind ex.html

39) ICTV, 2020. News. Available online at: https://talk.ictvonline.org/

40) Jenkins, C. \& Perrow, C. (1977). Insurgency of the powerless: farm worker movements (1946-1972). American Sociological Review, 42(2), pp. 249-68. https://doi.org/10.2307/2094604

41) Jugantor, (2020). ইউপি চেয়ারম্যানের বিরুদ্ধে চাল বিতরণে অনিয়মের অভিযোগ. [Accessed 6 May 2020].

42) Jugantor, (2020). করোনা প্রতিষেধকের গুজব, হোমিও চিকিৎসককে জরিমানা. Available at: https://www.jugantor.com/country-news/291209

43) Jugantor, (2020). ফেসবুকে-করোনার-গুজবছড়ানোয়-যুবলীগ-নেতা-গ্রেফতার. Available at: https://www.jugantor.com/country-news/294422 
44) Jugantor, (2020). করোনা ভাইরাস: কোচিং চালু রাখায় ২ শিক্ষককে আটক. Available at:

https://www.jugantor.com/country-news/290804

45) Jugantor, (2020). কিশোরগঞ্জে করোনা আক্রান্তের গুজব ছড়িয়ে চাদাদাবী ২ এসআইয়ের. Available at:

https://www.jugantor.com/country-news/290551

46) Jugantor, (2020). খাদ্য সামগ্রী না পেয়ে গোদাগাড়ীতে হোটেল শ্রমিকদের বিক্ষোভ. [Accessed 6 May 2020].

47) Jugantor, (2020). গুজবে রোগীশূন্য মনপুরা হাসপাতাল. Available at:

https://www.jugantor.com/covid-19/294802/

48) Jugantor, (2020). চট্টগ্রামে করোনা নিয়ে গুজব ছড়ানোয় গ্রেফতার S. Available at:

https://www.jugantor.com/todays-paper/news/2 90639/

49) Jugantor, (2020). ডেমরায় ত্রাণে এ দাবিতে সিএনজি চালক ও শ্রমিকদের মানববন্ধন. Available at: https://www.jugantor.com/covid-19/298809/

50) Jugantor, (2020). ত্রাণের দাবিতে মিরপুরে সড়ক আটকে বিহারিদের বিক্ষোভ. Available at: https://www.jugantor.com/covid-19/299944/

51) Jugantor, (2020). ত্রাণের দাবিতে রাস্তায় গাড়ির সামনে শুয়ে পড়ল উলিপুরের মানুষ. Available at: https://www.jugantor.com/covid-19/298838/

52) Jugantor, (2020). দিনাজপুরে শ্রমিকদের সঙ্গে পুলিশের সংঘর্ষ, গুলিতে চা দোকানদার নিহুত. Available at:

https://www.jugantor.com/country-news/292907

53) Jugantor, (2020). দেশে তিন করোনা রোগী শনাক্ত. Available at:

https://epaper.jugantor.com/2020/03/09/

54) Jugantor, (2020). রংপুরে ও গাইবান্ধায় চিনিকল শ্রমিকদের বকেয়া বেতনের দাবিতে বিক্ষোভ. Available at:

https://www.jugantor.com/todays-paper/news/3 02013/

55) Jugantor, (2020). লক ডাউন অমান্য করে সরকারি কর্মকর্তার বিয়ে. Available at:

https://www.jugantor.com/todays-paper/secondedition/297003/

56) Jugantor, (2020). সোনারগাওয়ে করোনার টিকা, ২ জনকে গণধোলাই দিয়ে জুতার মালা. Available at:

https://www.jugantor.com/country-news/291894
57) Kaler Kantho, (2020). হোম কোয়ারেন্টিনে থাকা নিয়ে সংঘর্ষ. Available at:

https://www.kalerkantho.com/online/country-n ews/2020/04/01/893373

58) Koopmans, R. (1993). The Dynamics of Protest Waves: West Germany, 1965 to 1989. American Sociological Review, 58(5), pp. 637-658. https://doi.org/10.2307/2096279

59) Naya Diganta, (2020). রাঙ্গাবালীতে ভিজিএফ সুবিধা বঞ্চিত জেলেদের অবস্থান কর্মসূচি. Available at:

https://www.dailynayadiganta.com/barishal/497 $\underline{561 /}$

60) New Age, (2020). 5 journalists sued in Thakurgaon. Available at:

https://www.newagebd.net/article/104737/5-jour nalists-sued-in-thakurgaon

61) New Age, (2020). Bangladesh university students boycott classes, exams. Available at: https://www.newagebd.net/article/102355/bangl adesh-university-students-boycott-classes-exams

62) New Age, (2020). Brahmanbaria civil surgeon hosts wedding reception ignoring ban on gathering. Available at:

https://www.newagebd.net/article/102840/brahm anbaria-civil-surgeon-hosts-wedding-receptionignoring-ban-on-gathering

63) New Age, (2020). City cleaners want COVID compensation. Available at:

https://www.newagebd.net/article/105398/citycleaners-want-covid-compensation

64) New Age, (2020). Coronavirus: 25,000 people attend Lakshmipur prayer. Available at: https://epaper.newagebd.net/detail/223618/2296

65) New Age, (2020). Ctg physician held for spreading rumor over coronavirus. Available at: https://epaper.newagebd.net/detail/224139/4063

66) New Age, (2020). Destitute women, children throng street corners for relief as shutdown continues. Available at:

https://www.newagebd.net/article/105073/destit ute-women-children-throng-street-corners-forrelief-as-shutdown-continues

67) New Age, (2020). Foreigners also defy mandatory quarantine in ctg. Available at: https://epaper.newagebd.net/detail/224705/4343 
68) New Age, (2020). Mob burns boat for carrying COVID-19 suspects. Available at: https://www.newagebd.net/article/104572/mobburns-boat-for-carrying-covid-19-suspects

69) New Age, (2020). People continuen to leave Dhaka in good carrying vehicles. Available at: https://epaper.newagebd.net/detail/225045/8026

70) New Age, (2020). People defy national shutdown in search of food and work. Available at: https://www.newagebd.net/article/103510/peopl e-defy-national-shutdown-in-search-of-food-an d-work\#

71) New Age, (2020). Protests halt coronavirus hospital construction. Available at: https://www.newagebd.net/article/103337/protes ts-halt-coronavirus-hospital-construction

72) New Age, (2020). Returnee flees hospital, in home quarantine. Available at: https://epaper.newagebd.net/detail/222189/8586

73) New Age, (2020). SKOP demands rations for jobless worker. Available at: https://epaper.newagebd.net/19-04-2020/2

74) New Age, (2020). Teachers jailed for private tuition defying govt restriction. Available at: https://www.newagebd.net/article/102635/teache rs-jailed-for-private-tuition-defying-govt-restriction

75) New Age, (2020). Transport workers stage demo for relief. Available at: https://www.newagebd.net/article/105434/transp ort-workers-stage-demo-for-relief

76) Olzak, S. (1992). The Dynamics of Ethnic Competition and Conflict. Stanford: Stanford University Press.
77) Prothom Alo, (2020). 'হোম কোয়ারেন্টিনের' নির্দেশনা অমান্য, জরিমানা. Available at: https://www.prothomalo.com/bangladesh/article/ 1645066/

78) Prothom Alo, (2020). Four arrested for storing COVID-19 test kits. [Online] Available at:

https://en.prothomalo.com/bangladesh/crime-an d-law/four-arrested-for-storing-covid-19-testkits

79) Prothom Alo, (2020). Thousands join Janaza in Brahmanbaria flouting social distancing rule. Available at:

https://en.prothomalo.com/bangladesh/thousands -join-janaza-in-brahmanbaria-flouting-social-dis tancing-rule

80) Prothom Alo, (2020). দোকান বন্ধ করতে বলায় গরম পানি ছুড়লেন চাবিক্রেতা. Available at:

https://www.prothomalo.com/bangladesh/article/ $\underline{1649230 /}$

81) Prothom Alo, (2020). সৈয়দ নজরুল মেডিকেলে করোনা চিকিৎসার সিদ্ধান্ত, প্রতিবাদে বিক্ষোভ. Available at:

https://www.prothomalo.com/bangladesh/article/ $\underline{1650431 /}$

82) Tarrow, S. G. (1989). Democracy and Disorder: Protest and Politics in Italy, 1965-1975. Oxford: Clarendon Press.

83) Taylor, C. \& Jodice, D. (1983). World Handbook of Political and Social Indicators. New Haven, CT: Yale University Press.

Citation: Nahid AHM. (2021). Resistance, unrest, protest and demonstration provoked by COVID-19: a case study of Bangladesh, Asian J. Soc. Sci. Leg. Stud., 3(2), 23-34. https://doi.org/10.34104/ajssls.021.023034 @ 